\title{
Genomic Diversity of the SARS-CoV-2 in Turkey and the Impact of Virus Genome Mutations on Clinical Outcomes
}

Ilker Karacan ${ }^{1,2 \dagger}$, Tugba Kizilboga Akgun ${ }^{1 \dagger}$, Nihat Bugra Agaoglu ${ }^{1,3}$, Payam Zolfagharian ${ }^{1}$, Mehtap Aydin ${ }^{4}$, Gizem Alkurt ${ }^{1}$, Jale Yildiz ${ }^{1}$, Betsi Kose ${ }^{1}$, Nisan Denizce Can ${ }^{5}$, Ayse Serra Ozel $^{4}$, Nilsun Altunal ${ }^{4}$, Arzu Irvem ${ }^{6}$, Yasemin Kendir Demirkol ${ }^{7}$, Ozlem Akgun Dogan ${ }^{7}$, Levent Doganay ${ }^{1,8 *}$, Gizem Dinler Doganay ${ }^{1,5 *}$

${ }^{1}$ Genomic Laboratory (GLAB), Umraniye Training and Research Hospital, University of Health Sciences, Istanbul, Turkey

${ }^{2}$ Science and Advanced Technology Research Center, Istanbul Medeniyet University, Istanbul, Turkey

${ }^{3}$ Department of Medical Genetics, Umraniye Training and Research Hospital, University of Health Sciences, Istanbul, Turkey

${ }^{4}$ Department of Infectious Diseases and Clinical Microbiology, Umraniye Training and Research Hospital, University of Health Sciences, Istanbul, Turkey

${ }^{5}$ Department of Molecular Biology and Genetics, Istanbul Technical University, Istanbul, Turkey

${ }^{6}$ Department of Microbiology, Umraniye Training and Research Hospital, University of Health Sciences, Istanbul, Turkey

${ }^{7}$ Department of Pediatric Genetics, Umraniye Training and Research Hospital, University of Health Sciences, Istanbul, Turkey

${ }^{8}$ Department of Gastroenterology, Umraniye Training and Research Hospital, University of Health Sciences, Istanbul, Turkey

$\dagger$ These authors contributed equally.

*These authors have equal correspondence.

\section{Corresponding authors:}

Gizem Dinler Doganay, Ph.D. Molecular Biology and Genetics Department, Istanbul Technical University, Istanbul, Turkey. e-mail: gddoganay@itu.edu.tr Levent Doganay, MD. Genomic Laboratory (GLAB), Umraniye Training and Research Hospital, University of Health Sciences, Istanbul, Turkey. e-mail: levent.doganay@saglik.gov.tr 
36 COVID-19 is a viral respiratory disease caused by SARS-CoV-2 infection. Global efforts of

37 genomic surveillance of the virus give chance to track the spread of the pandemic. Global

38 emergence of some viral mutations called attention and various studies have been suggested

39 about increased infectivity of the virus. Herein, we sequenced viral genomes isolated from

40184 patients in Istanbul and analyzed clinical metadata for the investigation of any viral

41 mutation which affects the disease course of the host. We did not detect any viral mutations

42 affecting the disease outcome in our cohort. Besides, we observed intra-host mutations in

$4376 \%$ of the isolates. Insertion/deletion and stop-gain mutations are also significantly less

44 common among intra-host variants compared to consensus viral genome mutations.

45 Longitudinal genomic surveillance is essential for timely detection of any lineages that might

46 affect clinical outcome, the performance of diagnostic assays, or even the immunological

47 escape of the virus.

Keywords: SARS-CoV-2, COVID-19, genome diversity, mutation, intra-host mutation

\section{Introduction}

52 Since the first case at the end of 2019, the novel betacoronavirus SARS-CoV-2 has spread the 53 world rapidly by reaching more than 60 million affected people and 1.4 million deaths as of 54 November 2020. Host response to SARS-CoV-2 infection and clinical severity can show high 55 heterogeneity. While many cases do not show any symptoms, some COVID-19 patients 56 develop acute respiratory distress syndrome and other life-threatening symptoms such as 57 pulmonary edema or thrombotic coagulopathy (Huang et al., 2020). Older age, cardiovascular 58 disease, respiratory diseases, diabetes are among known risk factors for COVID-19 clinical 59 course (Jordan et al., 2020; Wu and McGoogan, 2020). Pathogenesis of the COVID-19 is still 60 poorly understood but older age, male sex, and several other factors have been shown 61 associated with increased mortality rates (Li, X. et al., 2020; Zhou et al., 2020). Evidence on multisystemic involvement of the disease provoked questions on the association between host genetic factors with clinical outcome (Initiative, 2020; Zeberg and Paabo, 2020). Host genetic

64 factors and their pathogenesis in disease severity is still needed to be elucidated.

65 It has been known that RNA viruses have a much higher mutation rate, which can provide 66 enhanced adaptation and virulence, compared to DNA viruses (Duffy, 2018; Lauring and 67 Andino, 2010). Mutations in the RNA-based genome of coronaviruses can arise due to 68 replication errors which may be reduced in coronaviruses due to their polymerases with 
69

70

71

proofreading mechanism (Minskaia et al., 2006; Snijder et al., 2003). Also, the RNA editing mechanism, which is a part of the host immunity, can trigger new mutation events in the viral genome (Harris and Dudley, 2015; Mangeat et al., 2003). Global efforts for sequencing SARS-CoV-2 genomes revealed that may be expected for a coronavirus, genome diversity is very low (Fauver et al., 2020). However, excessive global spreading can give the virus a chance for a natural selection of advantageous mutations resulting in increased infectivity. High throughput sequencing methods have been progressively used during the COVID-19 outbreak. Extensive viral genome analyses by laboratories all over the world have reached the identification of more than 225,000 records in the GISAID SARS-CoV-2 database in just one year. In the meantime, several questions about viral mutations and their effects on the patient's clinical outcomes have arisen. Recent studies claimed increased infectivity or fatality rates caused by a viral p.D614G mutation of spike protein (Becerra-Flores and Cardozo, 2020; Korber et al., 2020; Li, Q. et al., 2020). The p.D614G mutation, which is now dominating the global pandemic, has shown that it was present in retrospectively-sampled isolates in China in late January (Volz et al., 2020). However, there is not any consensus and solid evidence on the effects of this mutation in terms of infectivity or mortality rates among patients due to uncertainty whether the frequency of this mutation is caused by chance or natural selection (Grubaugh et al., 2020).

A global and continuous effort is needed for viral strain monitoring to detect any mutation which may lead to higher mortality or infectivity rate. In this study, we sequenced 184 viral genomes sampled mostly in Istanbul, between the 13th of April and the 24th of June 2020. All related clinical data has been collected and viral genome mutations were tested for any association with the patient's clinical outcome.

\section{Methods}

Patients and clinical evaluation: All patients enrolled in the study evaluated with the criteria defined by 'COVID-19 Diagnosis and Treatment Guide' published by the Turkish Ministry of Health. We grouped the patients as asymptomatic, mild, or severe according to the following conditions:

1. Asymptomatic: Patients without any clinical, radiological symptoms or any signs of the disease.

2. Mild: Patients with mild symptoms had respiratory symptoms such as cough and dyspnea, fever, headache, sore throat, runny nose, muscle and joint pain, extreme weakness, alteration in sense of smell and taste, diarrhea. 
3. Severe: Patients with severe symptoms had (1) respiratory rate $\geq 30$ breaths/min; (2) $\mathrm{SpO} 2 \leq 93 \%$ while breathing room air; (3) $\mathrm{PaO} 2 / \mathrm{FiO} 2 \leq 300 \mathrm{mmHg}$; (4) respiratory failure which requires mechanical ventilation; (5) shock; (6) combined with other organ failures, need to be admitted to ICU.

Viral RNA extraction, genome sequencing, and data analysis: Viral RNA extraction, library preparation, and sequencing were performed as described previously (Karacan et al., 2020). Briefly, RNA was extracted from nasopharyngeal swab samples using the High Pure Viral RNA Kit (Roche Life Science). The sequencing library was prepared with multiplexed PCR based target enrichment using CleanPlex SARS-CoV-2 Library Preparation Kit (Paragon Genomics Inc). Pooled libraries were sequenced on the Illumina NextSeq500 instrument.

Raw sequencing data were first demultiplexed and quality assessment was performed using the FASTQC program (Andrews, 2010). Adapter sequences were trimmed using cutadapt (Martin, 2011) and reads were aligned to the reference SARS-CoV-2 genome (NC_045512.2) using bwa-mem (Li, 2013). Primers were pruned using TrimPrimers script within the fgbio tool (http://fulcrumgenomics.github.io/fgbio/). Variant calling and consensus sequence generation were performed using Samtools ( $\mathrm{Li}$ et al., 2009) and iVAR (Grubaugh et al., 2019). Alternate bases with $10 \%$ frequency were called as variants and consensus sequences were generated for major alleles with at least 10x depth of coverage. Variant files for each isolate were converted to vcf files, which was further processed with BCFtools (Li, 2011) and annotated using ANNOVAR (Wang et al., 2010). Consensus genome sequences of isolates were aligned using MAFFT (Katoh et al., 2019). The neighbor $\square$ joining method was used to estimate phylogenies using aligned sequences and the tree was visualized using FigTree v1.4.4. Clade annotations were performed using Nextclade tool (https://clades.nextstrain.org). Statistical analysis: Descriptive statistics were used to present clinical data. Proportions and percentages were used for the categorical data and mean values and standard deviations were used for the continuous data. Statistical significance of categorical data was calculated by two-tailed Fisher's exact test. A value of $\mathrm{p}<0.05$ was considered statistically significant.

\section{Results}

Samples were collected from 184 patients in Turkey between the 13th of April and the 24th of June 2020. The majority of the samples were collected from Istanbul, the epicenter of the pandemic in Turkey. Overall, the study cohort includes 14 patients (8\%) who did not 
137 manifest any symptoms, 65 patients (\%37.6) have at least one comorbidity. Most of the

138 patients $(\mathrm{n}=128,73.1 \%)$ have a mild disease course. Detailed clinical features of enrolled 139 patients were presented in Table 1.

140

141 Common viral variants and genetic phylogeny: Prepared amplicon libraries were 142 sequenced on a NextSeq 500 instrument with an average output of $1.29 \pm 0.64$ million reads 143 per sample resulting in an average of 5,212 \pm 3,931 depth of coverage. In total, 316 different 144 nucleotide mutations were detected with an average count of 10.33 per sample. Among 145 analyzed viral isolates, 175 were non-synonymous, 116 were synonymous, 16 were non146 coding, six were insertion/deletion, and three were stop-gain mutations. The most 147 predominant mutation was $\mathrm{C}>\mathrm{U}$ transition which came up to $52.37 \%$ of total conversion. The 148 most frequent mutation among 184 isolates and their consequences on the genome was given 149 respectively in Table 2. Positions 241, 23403, 3037, and 14408 were found to harbor the 150 highest mutation which reoccurred in almost $97 \%$ of viral isolates in this study. Clade 151 assignment based on Nextstrain nomenclature showed that the most common clades were 152 20B (59.8\%) and 20A (33.7\%) whereas 19A (4.3\%) and 20C (2.2\%) were in the minority 153 (Figure 1).

155 Viral clades and mutations are not associated with clinical outcome: Moreover, we 156 compared the clinical findings of patients to the viral genome mutations and Nextstrain 157 clades. We selected two clades (20A and 20B) due to obtaining enough sampling in our 158 cohort and compared the clinical manifestations of the patients. As a result, patients infected 159 by these two virus clades showed similar clinical features. Similarly, we found no statistical 160 difference between viral genome mutations which were detected in at least 10 patients, and 161 clinical severity, intensive care unit needs, and being asymptomatic. These results showed 162 that commonly seen viral mutations and clades are not associated with clinical manifestations 163 of patients in this study. Of note, the p.Q57H variant in the ORF3a gene has a significantly 164 higher frequency in females $(79.8 \%)$ compared to males $(66 \%)$ with a p-value of 0.0472. 165 Conversely, GGG to AAC trinucleotide change at positions 28881-28883 located in the $\mathrm{N}$ 166 gene has been detected more frequently in males (48\%) compared to females (30.9\%) with a 167 p-value of 0.0236. A complete list of tested variants and clinical parameters was given in 168 Table 3. 
170 Possibly detrimental intra-host mutations are under negative selection: We generated consensus sequences of each isolate considering the major alleles ( $>50 \%$ of all reads) for genomic positions. Variant calling using NGS data revealed that 140 isolates $(76 \%)$ have polymorphic sites in which minor allele frequencies (MAF) range between 10-90\%. The rest of the samples have mutations only whose allelic frequency was over 90\%. We further focused on those polymorphic sites for the presence of any association to clinical parameters. However, we could not detect any significant association between the number of polymorphic variations and clinical data. Overall, we identified 430 polymorphic sites in this study, and $95(22.1 \%)$ of them were detected in at least two patients or identical to a consensus variant.

Further, we inspected those intra-host mutations for their occurrence events among isolates. Insertion and deletion mutations together with stop-gain mutations were more frequent in intra-host mutation events with statistical significance whereas non-coding variants were seen less in intra-host mutation events (Table 4). The overall frequencies of synonymous and nonsynonymous mutation events were found not to be statistically significant between intra-host and consensus mutations. We also compared intra-host mutation counts to the clinical manifestations of the patients and no significant difference was detected.

\section{Discussion}

SARS-CoV-2, which is an RNA virus, is spreading globally at an unprecedented speed. Naturally, it evolves and some mutations which may alter its virulence or infectivity can be expected. High throughput sequencing capacity of laboratories together with experiences with other pathogens give the research community the ability to follow-up this rapidly expanding infection closely. Genomics based viral outbreak monitoring gives chance to investigate transmission dynamics and clinical impact of mutations (Alm et al., 2020). Besides, chasing viral strains in the populations is very important not only observing local or global spread but also tracing any mutation that may worsen the clinical outcomes or creating the risk of vaccine escape in the future, too. The majority of the naturally occurring mutations are expected to be neutral but some may provide advantageous or deleterious to the pathogen. Deleterious mutations that result in decreased infectivity will quickly disappear; inversely advantageous mutations are possible to reach high frequency in the population. Of note, deciding whether a mutation is neutral or advantageous during a global pandemic can be sophisticated due to founder effect or sampling bias (Liu et al., 2020; Mavian et al., 2020; van Dorp et al., 2020). Herein, we analyzed whole-genome sequences of 184 SARS-CoV-2 
204 isolates in Istanbul which was the epicenter of the pandemic in Turkey, using a high 205 throughput sequencing method. We evaluated viral genomic changes for any association with 206 the clinical outcomes of the patients.

207 A recent study pointed out that the majority of the analyzed samples in the European region 208 consisted of $20 \mathrm{~A}$ and 20B clades according to Nextstrain nomenclature (Alm et al., 2020). 209 Similar to the European genomic surveillance study, 93.5\% of samples analyzed in this work 210 mostly belonged to the $20 \mathrm{~A}$ or $20 \mathrm{~B}$ clades. Isolates belonging to the $19 \mathrm{~A}$ and $20 \mathrm{C}$ clades 211 constituted $4.3 \%$ and $2.2 \%$ of all samples, respectively. Overall, we revealed that clade 212 distribution in Istanbul was highly similar to that in Europe. Considering the pandemic 213 outbreak in Turkey, it can be stated that the early introduction of the virus to Istanbul 214 originated from Europe.

215 There have been criticisms of viral genetic differences and their effects on clinical outcomes 216 of infected patients. Recent studies were unable to find any association between the clinical 217 features of patients and viral mutations or clades. Even if there is a possibility for an arising 218 mutation with potential pathological effects, there is not enough evidence to support this 219 hypothesis, yet. Zhang et al. reported that major lineages among virus isolates have no major 220 difference in clinical outcomes (Zhang et al., 2020). In this study, we are also unable to detect 221 any genetic changes among sequenced viral genomes which may cause different clinical 222 outcomes in terms of severity of the disease or manifesting symptoms. On the other hand, studies are suggesting viral genetic changes such as p.D614G mutation may play a role in pathogenicity or transmissibility (Hou et al., 2020; Korber et al., 2020). However, extensive genomic and functional studies are still needed to prove those findings. Together with some reports on the effects of p.D614G, the reason is still not known clearly whether this mutation became dominant due to evolutionary advantages, founder effect, or possible sampling bias in the western world (Grubaugh et al., 2020). Our dataset was underpowered to test any association between clinical manifestations and p.D614G mutation since more than $95 \%$ of our samples have this mutation.

231 Studies on SARS-CoV-2 genome variants are mainly focused to understand viral epidemiology, transmission dynamics, development of diagnostic assays, vaccines, and drugs. It is very difficult to determine the origins of each kind of genomic alteration, but large proportions of SARS-CoV-2 genome alterations are $\mathrm{C}>\mathrm{U}$ changes (Matyasek and Kovarik, 2020; Simmonds, 2020). This type of nucleotide change was shown to be mainly caused by host RNA-editing mechanisms, namely ADAR and APOBEC deaminase mechanisms, as a part of the host antiviral defense mechanism (Di Giorgio et al., 2020). In our data, 52.39\% of 
238 all conversions are $\mathrm{C}>\mathrm{U}$ transitions. Since the deamination in humans is known to be a driver 239 of mutational events and associated with a variety of diseases, clinical outcomes of COVID24019 patients might also be associated with this antiviral defense mechanism.

241 During the SARS-CoV-2 pandemic, high throughput sequencing has been globally used for 242 viral genome analysis to uncover transmission patterns and evolutionary dynamics of the 243 virus. Thus, this pandemic was the first in which researchers were able to continuously track 244 genomic changes. Inter-host consensus sequences of the pathogen genome are always used 245 for epidemiological investigations. However, these consensus sequences ignore the intra-host 246 genomic variations of the virus population within the host. Besides all mutation events 247 originated from an intra-host mutation, monitoring those events is also crucial to study its 248 evolution dynamics. These intra-host variations of the virus genome may cause the 249 immunological escape of the virus or affect the diagnostic performance of molecular assays. 250 High-quality data of the deep sequencing methodologies give an opportunity to sensitively 251 detect intra-host variations with minor allele frequencies (MAF) as low as 5\%. In this study, 252 we detected a total of 430 intra-host unique mutations with MAF between $10-90 \%$ in $76 \%$ of 253 all samples. Our results indicated that subclonal mutations of the SARS-CoV-2 genome are 254 prevalent among clinical samples. Also, 22.1\% of those unique mutations occurred in at least 255 two patients or identical to a consensus variant. This also indicates that the majority of those 256 mutational events are not localized in hotspot sites.

257 Our results were highly similar to Rose et al. who reported intra-host mutations in $72 \%$ of 258 analyzed 406 isolates (Rose et al., 2020). Of note, the number of intra-host variation events 259 was not comparable since the conditions for the definition of polymorphic is not clear in the 260 preprint article by Rose et al. whereas we used intra-host mutation definition if MAF was 261 between $10 \%$ and $90 \%$ for a called variant.

262 A closer look at these polymorphic sites revealed that frequencies of non-synonymous and 263 synonymous variants were not statistically different than inter-host variations (MAF > 90\%) 264 in the cohort. Whereas frequencies of stop-gain, in/del, and noncoding variants differ 265 between intra- and inter-host variations. Stop-gain and in/del mutations were observed more 266 in intra-host variations compared to inter-host consensus variants with MAF $>90 \%$. Insertion 267 and deletions were detected at $5 \%$ and $0.9 \%$ in all intra- and inter-host variants, respectively. 268 Similarly, the stop-gain variation rate in inter-host variations was $0.12 \%$ whereas its 269 frequency in inter-host variations was ten times more: 1.2\%. This result may be due to 270 possible detrimental effects of those mutations by reducing viral activity. 
271 Even though polymorphic sites might also be caused by amplification or sequencing errors,

272 detection of those variants with different sequencing methodologies indicates the presence of 273 intra-host variants. We also considered if these intra-host variations were caused by mixed 274 infections but there is not any statistical difference in the occurrence of intra-host variations 275 between outpatient and hospitalized groups. Further investigations about intra-host mutations 276 are still required for understanding SARS-CoV-2 genome dynamics.

277 To conclude, our results were not able to identify any significant SARS-CoV-2 mutation 278 related to the patient's clinical manifestations or severity of the disease at this stage. Besides, 279 we report mostly unique intra-host mutations in $76 \%$ of the samples with MAF ranging 280 between $10-90 \%$, indicating continuous intra-host mutational events are very common. Since 281 those mutations might be an origin for a lineage causing immunological escape of the virus, 282 further longitudinal global genomic surveillance is needed.

283

\section{Acknowledgements}

285 We thank the patients for their contribution to this study. This work was supported by a grant 286 from the Health Institutes of Turkey (TUSEB Grant No: 8799).

\section{Author contributions}

289 Conceptualization, L.D., G.D.D, I.K.; Data, T.K.A., N.B.A., M.A., N.D.C., A.S.O., N.A., 290 A.I., Y.K.D., O.A.D.; Clinical sample management, T.K.A., N.B.A., P.Z., G.A., J.Y., B.K.; 291 High-throughput sequencing, T.K.A., G.A., J.Y., B.K.; Analysis, I.K., P.Z.; Writing 292 Original Draft, I.K.; Writing - Review \& Editing, I.K., N.B.A., L.D., G.D.D.

\section{Declaration of interests}

295 The authors declare no competing interests.

Tables

Table 1: Demographic and clinical characteristics of 184 COVID-19 patients.

\begin{tabular}{|c|c|}
\hline Age (years, mean $\pm \mathrm{SD})$ & $49.7 \pm 19.5$ \\
\hline Male gender (n, \%) & $100(54.3 \%)$ \\
\hline \multicolumn{2}{|c|}{ Co-existing condition (n, \%) } \\
\hline Hypertension & $39(21.5 \%)$ \\
\hline
\end{tabular}


medRxiv preprint doi: https://doi.org/10.1101/2020.12.25.20248851; this version posted December 30, 2020. The copyright holder for this preprint (which was not certified by peer review) is the author/funder, who has granted medRxiv a license to display the preprint in perpetuity.

\begin{tabular}{|c|c|}
\hline Diabetes & $38(22.1 \%)$ \\
\hline Heart disease & $11(6.4 \%)$ \\
\hline COPD & $16(9.3 \%)$ \\
\hline \multicolumn{2}{|l|}{ Symptoms (n, \%) } \\
\hline Yes & $161(92 \%)$ \\
\hline No & $14(8 \%)$ \\
\hline \multicolumn{2}{|l|}{ Chest CT findings (n, \%) } \\
\hline Normal & $35(23.5 \%)$ \\
\hline Mild & $59(39.6 \%)$ \\
\hline Severe & $42(28.2 \%)$ \\
\hline Critical & $13(8.7 \%)$ \\
\hline \multicolumn{2}{|l|}{ Clinical severity (n, \%) } \\
\hline Asymptomatic & $14(8 \%)$ \\
\hline Mild & $128(73.1 \%)$ \\
\hline Severe & $33(18.9 \%)$ \\
\hline \multicolumn{2}{|l|}{$\operatorname{ICU}(\mathrm{n}, \%)$} \\
\hline Yes & $19(10.8 \%)$ \\
\hline No & $157(89.2 \%)$ \\
\hline \multicolumn{2}{|l|}{ Death $(\mathrm{n}, \%)$} \\
\hline Yes & $12(6.9 \%)$ \\
\hline No & $163(93.1 \%)$ \\
\hline \multicolumn{2}{|l|}{ Biochemical parameters } \\
\hline Leukocyte count $\left(\times 10^{-9}\right.$, normal range: $\left.4,000-10,000\right)$ & $5928,76 \pm 2344,74$ \\
\hline Lymphocyte count $\left(\times 10^{-9}\right.$, normal range: $\left.700-4,000\right)$ & $1733,70 \pm 775,68$ \\
\hline C-reactive protein $(\mathrm{mg} / \mathrm{dL}$, normal range: 0 - 0.5$)$ & $3,91 \pm 5,61$ \\
\hline Lactate dehydrogenase (U/L, normal range: 125 - 220) & $341,28 \pm 146,45$ \\
\hline
\end{tabular}


medRxiv preprint doi: https://doi.org/10.1101/2020.12.25.20248851; this version posted December 30, 2020. The copyright holder for this preprint (which was not certified by peer review) is the author/funder, who has granted medRxiv a license to display the preprint in perpetuity.

It is made available under a CC-BY-NC-ND 4.0 International license .

299

300

301

302

\begin{tabular}{|l|l|}
\hline D-dimer (ng/ml, normal range: 0 - 500) & $1123,23 \pm 1245,39$ \\
\hline Ferritin (ng/ml, normal ranges female:5-204, male: $22-275)$ & $572,94 \pm 843,78$ \\
\hline
\end{tabular}

Table 2: The most common mutations and amino acid changes in SARS-CoV-2 genomes

\begin{tabular}{|c|c|c|c|c|c|}
\hline Position & $\begin{array}{c}\text { Percentage in } \\
\text { all samples }\end{array}$ & Change & Effect & Gene / Region & $\begin{array}{c}\text { Amino acid } \\
\text { change }\end{array}$ \\
\hline 241 & $97.2 \%$ & $\mathrm{C} / \mathrm{T}$ & Non-coding & ORF1a & NA \\
\hline 23403 & $97.2 \%$ & $\mathrm{~A} / \mathrm{G}$ & missense & $\mathrm{S}$ & $\mathrm{D} / \mathrm{G}$ \\
\hline 3037 & $96.1 \%$ & $\mathrm{C} / \mathrm{T}$ & synonymous & ORF1a & $\mathrm{F} / \mathrm{F}$ \\
\hline 14408 & $95.6 \%$ & $\mathrm{C} / \mathrm{T}$ & missense & ORF1b & $\mathrm{P} / \mathrm{L}$ \\
\hline $28881-28882$ & $61.4 \%$ & $\mathrm{GG} / \mathrm{AA}$ & missense & $\mathrm{N}$ & $\mathrm{R} / \mathrm{K}$ \\
\hline 28883 & $60.8 \%$ & $\mathrm{G} / \mathrm{C}$ & missense & $\mathrm{N}$ & $\mathrm{G} / \mathrm{R}$ \\
\hline 12809 & $30.9 \%$ & $\mathrm{C} / \mathrm{T}$ & missense & ORF1a & $\mathrm{L} / \mathrm{F}$ \\
\hline 25563 & $27.6 \%$ & $\mathrm{G} / \mathrm{T}$ & missense & ORF3a & $\mathrm{Q} / \mathrm{H}$ \\
\hline 18877 & $25.5 \%$ & $\mathrm{C} / \mathrm{T}$ & synonymous & ORF1b & $\mathrm{L} / \mathrm{L}$ \\
\hline 19839 & $23.3 \%$ & $\mathrm{~T} / \mathrm{C}$ & synonymous & ORF1b & $\mathrm{N} / \mathrm{N}$ \\
\hline
\end{tabular}

303

304

305

306

Table 3: Selected SARS-CoV-2 variants in the study and two-sided Fisher's exact test results.

\begin{tabular}{|l|c|c|c|c|c|}
\hline & & \multicolumn{3}{|c|}{ p-value } \\
\hline $\begin{array}{l}\text { Nucleotide position and } \\
\text { change }\end{array}$ & Effect & Gender & $\begin{array}{c}\text { Manifest } \\
\text { symptoms }\end{array}$ & $\begin{array}{c}\text { Clinical } \\
\text { grade } \\
\text { Mild vs } \\
\text { Severe })\end{array}$ & ICU need \\
\hline $\begin{array}{l}\text { 2113:C>T } \\
\text { (ORF1ab:p.I616I) }\end{array}$ & syn & 0.6669 & 1.0000 & 0.5715 & 0.3182 \\
\hline $\begin{array}{l}\text { 3037:C>T } \\
\text { (ORF1ab:p.F924F) }\end{array}$ & syn & 1.0000 & 1.0000 & 1.0000 & 0.6017 \\
\hline $\begin{array}{l}\text { 5730:C>T } \\
\text { (ORF1ab:p.T1822I) }\end{array}$ & non-syn & 0.5523 & 0.5365 & 0.6890 & 1.0000 \\
\hline $\begin{array}{l}\text { 12809:C>T } \\
\text { (ORF1ab:p.L4182F) }\end{array}$ & non-syn & 0.0532 & 1.0000 & 0.6756 & 0.6106 \\
\hline
\end{tabular}


medRxiv preprint doi: https://doi.org/10.1101/2020.12.25.20248851; this version posted December 30, 2020. The copyright holder for this preprint (which was not certified by peer review) is the author/funder, who has granted medRxiv a license to display the preprint in perpetuity.

It is made available under a CC-BY-NC-ND 4.0 International license .

\begin{tabular}{|l|c|c|c|c|c|}
\hline $\begin{array}{l}\text { 14408:C>T } \\
\text { (ORF1ab:p.P4715L) }\end{array}$ & non-syn & 1.0000 & 1.0000 & 1.0000 & 0.6034 \\
\hline $\begin{array}{l}\text { 17104:C>T } \\
\text { (ORF1ab:p.H5614Y) }\end{array}$ & non-syn & 1.0000 & 0.6021 & 0.4621 & 1.0000 \\
\hline $\begin{array}{l}\text { 17690:C>T } \\
\text { (ORF1ab:p.S5809L) }\end{array}$ & non-syn & 0.0507 & 0.5275 & 0.1587 & 0.2505 \\
\hline $\begin{array}{l}\text { 18877:C>T } \\
\text { (ORF1ab:p.L6205L) }\end{array}$ & syn & 0.0891 & 0.3558 & 0.8204 & 0.7844 \\
\hline $\begin{array}{l}\text { 19839:T>C } \\
\text { (ORF1ab:p.N6525N) }\end{array}$ & syn & 0.7266 & 0.3215 & 0.1073 & 0.7754 \\
\hline $\begin{array}{l}\text { 20629:C>T } \\
\text { (ORF1ab:p.H6789Y) }\end{array}$ & non-syn & 0.7733 & 1.0000 & 0.4616 & 1.0000 \\
\hline $\begin{array}{l}\text { 23403:A>G } \\
\text { (S:p.D614G) }\end{array}$ & non-syn & 0.7291 & 1.0000 & 1.0000 & 1.0000 \\
\hline $\begin{array}{l}\text { 25563:G>T } \\
\text { (ORF3a:p.Q57H) }\end{array}$ & non-syn & $\mathbf{0 . 0 4 7 2}$ & 0.7623 & 0.6556 & 0.7839 \\
\hline $\begin{array}{l}\text { 25611:C>A } \\
\text { (ORF3a:p.L73L) }\end{array}$ & syn & 1.0000 & 1.0000 & 0.2739 & 0.6354 \\
\hline $\begin{array}{l}\text { 28881-28883:GGG>AAC } \\
\text { (N:p.RG203-204KR) }\end{array}$ & non-syn & $\mathbf{0 . 0 2 3 6}$ & 0.5701 & 0.4323 & 1.0000 \\
\hline
\end{tabular}

Table 4: Amounts of intra-host and consensus mutation events among all 184 samples and their functional effects. AF: intra-host allelic frequency of the variant.

\begin{tabular}{|l|l|l|l|}
\hline & $\begin{array}{c}\text { Intra-host mutation } \\
\text { events } \\
(10 \%<\mathrm{AF}<90 \%)\end{array}$ & $\begin{array}{c}\text { Consensus mutations } \\
(\mathrm{AF}>90 \%)\end{array}$ & $\mathrm{p}$-value \\
\hline Non-synonymous & 469 & 857 & 1.0000 \\
\hline Synonymous & 317 & 526 & 0.2621 \\
\hline $\begin{array}{l}\text { Insertion and } \\
\text { deletion }\end{array}$ & 46 & 15 & $<\mathbf{0 . 0 0 0 1}$ \\
\hline Stop-gain & 11 & 2 & $\mathbf{0 . 0 0 0 4}$ \\
\hline Non-coding & 35 & 201 & $\mathbf{0 . 0 0 0 1}$ \\
\hline
\end{tabular}




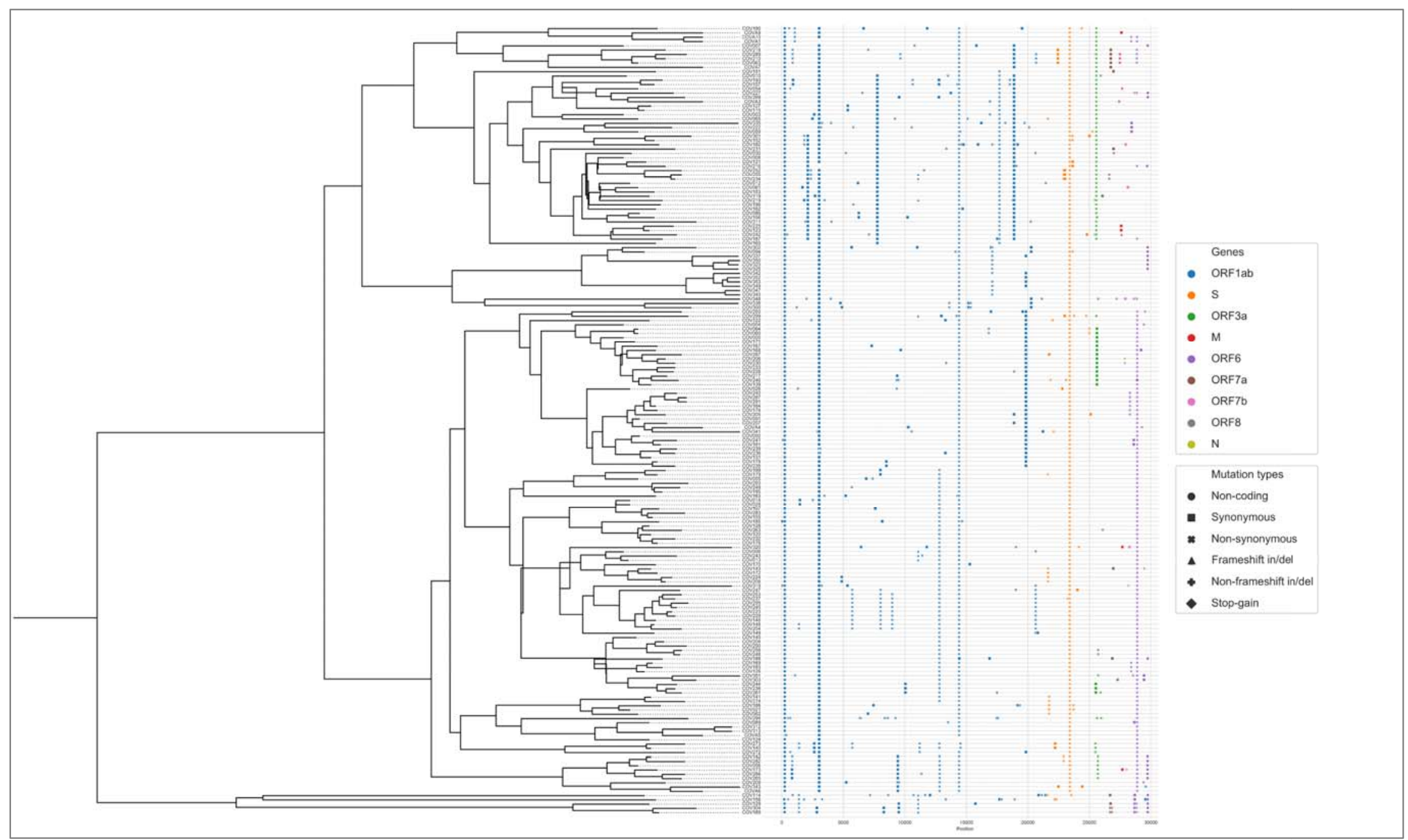




\section{References}

315 Alm, E., Broberg, E.K., Connor, T., Hodcroft, E.B., Komissarov, A.B., Maurer-Stroh, S., 316 Melidou, A., Neher, R.A., O'Toole, A., Pereyaslov, D., et al. (2020). Geographical and 317 temporal distribution of SARS-CoV-2 clades in the WHO European Region, January to June 318 2020. Euro Surveill. 25(32). Published online 2020/08/15 DOI: 10.2807/1560319 7917.ES.2020.25.32.2001410.

320 Andrews, S., 2010. FastQC: A Quality Control Tool for High Throughput Sequence Data. 321 Available online at: http://www.bioinformatics.babraham.ac.uk/projects/fastqc/.

322 Becerra-Flores, M., and Cardozo, T. (2020). SARS-CoV-2 viral spike G614 mutation 323 exhibits higher case fatality rate. Int J Clin Pract. 74(8), e13525. Published online 2020/05/07 324 DOI: 10.1111/ijcp.13525.

325 Di Giorgio, S., Martignano, F., Torcia, M.G., Mattiuz, G., and Conticello, S.G. (2020). 326 Evidence for host-dependent RNA editing in the transcriptome of SARS-CoV-2. Sci Adv. 327 6(25), eabb5813. Published online 2020/07/01 DOI: 10.1126/sciadv.abb5813.

328 Duffy, S. (2018). Why are RNA virus mutation rates so damn high? PLoS Biol. 16(8), e3000003. Published online 2018/08/14 DOI: 10.1371/journal.pbio.3000003.

Fauver, J.R., Petrone, M.E., Hodcroft, E.B., Shioda, K., Ehrlich, H.Y., Watts, A.G., Vogels, SARS-CoV-2 during the Early Epidemic in the United States. Cell. 181(5), 990-996 e995. Published online 2020/05/11 DOI: 10.1016/j.cell.2020.04.021.

334 Grubaugh, N.D., Gangavarapu, K., Quick, J., Matteson, N.L., De Jesus, J.G., Main, B.J., Tan, 335 A.L., Paul, L.M., Brackney, D.E., Grewal, S., et al. (2019). An amplicon-based sequencing 336 framework for accurately measuring intrahost virus diversity using PrimalSeq and iVar. 337 Genome Biol. 20(1), 8. Published online 2019/01/10 DOI: 10.1186/s13059-018-1618-7.

338 Grubaugh, N.D., Hanage, W.P., and Rasmussen, A.L. (2020). Making Sense of Mutation: 339 What D614G Means for the COVID-19 Pandemic Remains Unclear. Cell. 182(4), 794-795. 340 Published online 2020/07/23 DOI: 10.1016/j.cell.2020.06.040.

341 Harris, R.S., and Dudley, J.P. (2015). APOBECs and virus restriction. Virology. 479-480, 342 131-145. Published online 2015/03/31 DOI: 10.1016/j.virol.2015.03.012.

343 Hou, Y.J., Chiba, S., Halfmann, P., Ehre, C., Kuroda, M., Dinnon, K.H., 3rd, Leist, S.R., 344 Schafer, A., Nakajima, N., Takahashi, K., et al. (2020). SARS-CoV-2 D614G variant exhibits 345 efficient replication ex vivo and transmission in vivo. Science. Published online 2020/11/14 346 DOI: $10.1126 /$ science.abe8499.

347 Huang, C., Wang, Y., Li, X., Ren, L., Zhao, J., Hu, Y., Zhang, L., Fan, G., Xu, J., Gu, X., et 348 al. (2020). Clinical features of patients infected with 2019 novel coronavirus in Wuhan, 349 China. Lancet. 395(10223), 497-506. Published online 2020/01/28 DOI: 10.1016/S0140350 6736(20)30183-5.

351 Initiative, C.-H.G. (2020). The COVID-19 Host Genetics Initiative, a global initiative to 352 elucidate the role of host genetic factors in susceptibility and severity of the SARS-CoV-2 
353 virus pandemic. Eur J Hum Genet. 28(6), 715-718. Published online 2020/05/15 DOI: 354 10.1038/s41431-020-0636-6.

355 Jordan, R.E., Adab, P., and Cheng, K.K. (2020). Covid-19: risk factors for severe disease and 356 death. BMJ. 368, m1198. Published online 2020/03/29 DOI: 10.1136/bmj.m1198.

357 Karacan, I., Akgun, T.K., Agaoglu, N.B., Irvem, A., Alkurt, G., Yildiz, J., Kose, B., Ozel, 358 A.S., Altunal, L.N., Can, N.D., et al. (2020). The origin of SARS-CoV-2 in Istanbul: 359 Sequencing findings from the epicenter of the pandemic in Turkey. North Clin Istanb. 7(3), 360 203-209. Published online 2020/06/02 DOI: 10.14744/nci.2020.90532.

361 Katoh, K., Rozewicki, J., and Yamada, K.D. (2019). MAFFT online service: multiple 1160-1166. Published online 2017/10/03 DOI: 10.1093/bib/bbx108.

Korber, B., Fischer, W.M., Gnanakaran, S., Yoon, H., Theiler, J., Abfalterer, W., Hengartner, N., Giorgi, E.E., Bhattacharya, T., Foley, B., et al. (2020). Tracking Changes in SARS-CoV2 Spike: Evidence that D614G Increases Infectivity of the COVID-19 Virus. Cell. 182(4), 812-827 e819. Published online 2020/07/23 DOI: 10.1016/j.cell.2020.06.043.

Lauring, A.S., and Andino, R. (2010). Quasispecies theory and the behavior of RNA viruses. 369 PLoS Pathog. 6(7), e1001005. Published online 2010/07/28 DOI: 370 10.1371/journal.ppat.1001005.

Li, H. (2011). A statistical framework for SNP calling, mutation discovery, association mapping and population genetical parameter estimation from sequencing data. Bioinformatics. 27(21), 2987-2993. Published online 2011/09/10 DOI: 10.1093/bioinformatics/btr509.

375 Li, H. (2013). Aligning sequence reads, clone sequences and assembly contigs with BWA376 MEM. arXiv preprint arXiv:1303.3997.

377 Li, H., Handsaker, B., Wysoker, A., Fennell, T., Ruan, J., Homer, N., Marth, G., Abecasis, 378 G., Durbin, R., and Genome Project Data Processing, S. (2009). The Sequence 379 Alignment/Map format and SAMtools. Bioinformatics. 25(16), 2078-2079. Published online 380 2009/06/10 DOI: 10.1093/bioinformatics/btp352.

381 Li, Q., Wu, J., Nie, J., Zhang, L., Hao, H., Liu, S., Zhao, C., Zhang, Q., Liu, H., Nie, L., et al. 382 (2020). The Impact of Mutations in SARS-CoV-2 Spike on Viral Infectivity and 383 Antigenicity. Cell. 182(5), 1284-1294 e1289. Published online 2020/07/31 DOI: 384 10.1016/j.cell.2020.07.012.

385 Li, X., Xu, S., Yu, M., Wang, K., Tao, Y., Zhou, Y., Shi, J., Zhou, M., Wu, B., Yang, Z., et al. (2020). Risk factors for severity and mortality in adult COVID-19 inpatients in Wuhan. J Allergy Clin Immunol. 146(1), 110-118. Published online 2020/04/16 DOI: 10.1016/j.jaci.2020.04.006. al. (2020). Population Genetics of SARS-CoV-2: Disentangling Effects of Sampling Bias and Infection Clusters. Genomics Proteomics Bioinformatics. Published online 2020/07/15 DOI: 10.1016/j.gpb.2020.06.001. 
393 Mangeat, B., Turelli, P., Caron, G., Friedli, M., Perrin, L., and Trono, D. (2003). Broad 394 antiretroviral defence by human APOBEC3G through lethal editing of nascent reverse 395 transcripts. Nature. 424(6944), 99-103. Published online 2003/06/17 DOI: $39610.1038 /$ nature01709.

397 Martin, M. (2011). Cutadapt removes adapter sequences from high-throughput sequencing 398 reads. 2011. 17(1), 3. Published online 2011-08-02 DOI: 10.14806/ej.17.1.200.

399 Matyasek, R., and Kovarik, A. (2020). Mutation Patterns of Human SARS-CoV-2 and Bat 400 RaTG13 Coronavirus Genomes Are Strongly Biased Towards C>U Transitions, Indicating 401 Rapid Evolution in Their Hosts. Genes (Basel). 11(7). Published online 2020/07/11 DOI: 402 10.3390/genes11070761.

403 Mavian, C., Pond, S.K., Marini, S., Magalis, B.R., Vandamme, A.M., Dellicour, S., Scarpino, 404 S.V., Houldcroft, C., Villabona-Arenas, J., Paisie, T.K., et al. (2020). Sampling bias and 405 incorrect rooting make phylogenetic network tracing of SARS-COV-2 infections unreliable. 406 Proc Natl Acad Sci U S A. 117(23), 12522-12523. Published online 2020/05/10 DOI: 407 10.1073/pnas.2007295117.

408 Minskaia, E., Hertzig, T., Gorbalenya, A.E., Campanacci, V., Cambillau, C., Canard, B., and 409 Ziebuhr, J. (2006). Discovery of an RNA virus 3'->5' exoribonuclease that is critically 410 involved in coronavirus RNA synthesis. Proc Natl Acad Sci U S A. 103(13), 5108-5113. 411 Published online 2006/03/22 DOI: 10.1073/pnas.0508200103.

412 Rose, R., Nolan, D.J., Moot, S., Feehan, A., Cross, S., Garcia-Diaz, J., and Lamers, S.L. 413 (2020). Intra-host site-specific polymorphisms of SARS-CoV-2 is consistent across multiple 414 samples and methodologies. medRxiv. 2020.2004.2024.20078691. DOI: 415 10.1101/2020.04.24.20078691.

416 Simmonds, P. (2020). Rampant C-->U Hypermutation in the Genomes of SARS-CoV-2 and 417 Other Coronaviruses: Causes and Consequences for Their Short- and Long-Term 418 Evolutionary Trajectories. mSphere. 5(3). Published online 2020/06/26 DOI: 419 10.1128/mSphere.00408-20.

420 Snijder, E.J., Bredenbeek, P.J., Dobbe, J.C., Thiel, V., Ziebuhr, J., Poon, L.L., Guan, Y., 421 Rozanov, M., Spaan, W.J., and Gorbalenya, A.E. (2003). Unique and conserved features of 422 genome and proteome of SARS-coronavirus, an early split-off from the coronavirus group 2 423 lineage. J Mol Biol. 331(5), 991-1004. Published online 2003/08/21 DOI: 10.1016/s0022424 2836(03)00865-9.

425 van Dorp, L., Richard, D., Tan, C.C.S., Shaw, L.P., Acman, M., and Balloux, F. (2020). No 426 evidence for increased transmissibility from recurrent mutations in SARS-CoV-2. Nat 427 Commun. 11(1), 5986. Published online 2020/11/27 DOI: 10.1038/s41467-020-19818-2.

428 Volz, E., Hill, V., McCrone, J.T., Price, A., Jorgensen, D., O'Toole, A., Southgate, J., 429 Johnson, R., Jackson, B., Nascimento, F.F., et al. (2020). Evaluating the Effects of SARS430 CoV-2 Spike Mutation D614G on Transmissibility and Pathogenicity. Cell. Published online 431 2020/12/05 DOI: 10.1016/j.cell.2020.11.020. 
medRxiv preprint doi: https://doi.org/10.1101/2020.12.25.20248851; this version posted December 30, 2020. The copyright holder for this preprint (which was not certified by peer review) is the author/funder, who has granted medRxiv a license to display the preprint in perpetuity.

It is made available under a CC-BY-NC-ND 4.0 International license .

432 Wang, K., Li, M., and Hakonarson, H. (2010). ANNOVAR: functional annotation of genetic 433 variants from high-throughput sequencing data. Nucleic Acids Res. 38(16), e164. Published 434 online 2010/07/06 DOI: 10.1093/nar/gkq603.

435 Wu, Z., and McGoogan, J.M. (2020). Characteristics of and Important Lessons From the 436 Coronavirus Disease 2019 (COVID-19) Outbreak in China: Summary of a Report of 72314

437 Cases From the Chinese Center for Disease Control and Prevention. JAMA. 323(13), 1239438 1242. Published online 2020/02/25 DOI: 10.1001/jama.2020.2648.

439 Zeberg, H., and Paabo, S. (2020). The major genetic risk factor for severe COVID-19 is 440 inherited from Neanderthals. Nature. 587(7835), 610-612. Published online 2020/10/01 DOI: 441 10.1038/s41586-020-2818-3.

442 Zhang, X., Tan, Y., Ling, Y., Lu, G., Liu, F., Yi, Z., Jia, X., Wu, M., Shi, B., Xu, S., et al. 443 (2020). Viral and host factors related to the clinical outcome of COVID-19. Nature. 444 583(7816), 437-440. Published online 2020/05/21 DOI: 10.1038/s41586-020-2355-0.

445 Zhou, F., Yu, T., Du, R., Fan, G., Liu, Y., Liu, Z., Xiang, J., Wang, Y., Song, B., Gu, X., et 446 al. (2020). Clinical course and risk factors for mortality of adult inpatients with COVID-19 in 447 Wuhan, China: a retrospective cohort study. Lancet. 395(10229), 1054-1062. Published 448 online 2020/03/15 DOI: 10.1016/S0140-6736(20)30566-3. 